\title{
Semi-Manual Processing of Blood Clamps Waste into Chitosan Powder
}

\author{
Chiesa Salsabila ${ }^{1}$, Candra Wahyuningsih ${ }^{1}$, Diana Ayu Fitriana ${ }^{1}$, Rina Sari Asih ${ }^{1}$, Rejeki Siti \\ Ferniah $^{1}$, Khoirin $\mathrm{Nida}^{2}$ \\ ${ }^{1}$ Biotechnology Study Program, Diponegoro University, Semarang, Indonesia \\ ${ }^{2}$ Biology Study Program, Diponegoro University, Semarang, Indonesia \\ *Corresponding author email: salsabilachiesa56@gmail.com
}

\begin{abstract}
Blood clams (Anadara granosa) are endemic clams found in Southeast Asia and East Asia. Blood clams are widely consumed by the public as seafood dishes in coastal food stalls. The great potential of blood clams will increase the waste of clam shells produced. The accumulation of shellfish waste will cause pollution and reduce environmental aesthetics. The chitin content in blood clam shells can be used as chitosan. Chitosan is a polymer of -(1-4) glucosamine which is formed when the acetyl group in chitin is substituted by hydrogen to become an amine group. Chitosan has antibacterial and antifungal properties. Isolation of chitosan was carried out through the stages of demineralization, deproteination, and deacetylation. The limited use of laboratories during the pandemic is a major obstacle in the isolation process of chitosan. This study aims to process blood clam shell waste into chitosan in a simple way on a home scale. Processing includes deproteination, demineralization, and deacetylation were done using tools and materials available at home. Laboratory equipment such as beakers could be replaced with pots, the reflux process was replaced by using a cloth to filter, and measuring cups were replaced with glasses. The research used 1500 grams of blood clam shell powder and produced 1050 grams of white chitosan with a slightly hard texture.
\end{abstract}

Keywords: Blood clam chitosan, deproteination, demineralization, depigmentation, deacetylation.

\section{Introduction}

Blood clam (Anadara granosa) is one of the marine biotas of the genus Anadara with the characteristics of having a clean white thick oval shell with a wavy surface (Dewi et al., 2019). This type of shellfish is often found in Southeast Asia and East Asia (Yurimoto, 2013). The high level of consumption of blood clams in Indonesia which reaches the number 4,738 tons in 2011 causes the waste of blood clam shells to be quite abundant (Perikanan, 2011; Devi et al., 2019). So far, this waste has not been managed optimally so that it has an impact on polluting environment and reducing the beauty of the environment.

Blood clam shells are known to contain chitin which can be processed into chitosan (El Knidri et al., 2018). Chitosan is a polymer of -(1-4) glucosamine which is formed when a group of chitins have fully or partially deacetylated (Kumirska et al., 2010; Tolaimate et al., 2003). One of the uses of chitosan is that it has antibacterial and antifungal properties that can be applied to prevent contamination, especially in plants (Al-Hetar et al., 2011; Hassan and Chang, 2017). How to obtain chitosan can be done by isolating chitosan from blood clam shells which is carried out through 4 stages, namely demineralization, deproteination, depigmentation, and deacetylation.

During the pandemic, the limited use of laboratories became the main obstacle in the chitosan isolation process. This is because the isolation process requires tools and materials available in the laboratory. Based on these problems, this study aims to process blood clam shell waste into simple chitosan on a home scale. The process carried out in the research is a process of modification and innovation by utilizing simple equipment and is expected to help provide a reference for making chitosan independently.

\section{Methodology}

\subsection{Demineralization}

Blood clam shell powder was soaked in $1 \mathrm{~N} \mathrm{HCl}$ with a ratio of $1: 2 \mathrm{w} / \mathrm{v}$, then heated in a saucepan at $100^{\circ} \mathrm{C}$ for 1 hour, stirring every 10 minutes. When finished, let it sit for a few hours to cool and the shell powder settles, after that, the precipitate is filtered using a cloth while rinsing with sterile water/aquadest, then dried in an oven at $200^{\circ} \mathrm{C}$ for 10 minutes. 


\subsection{Deproteination}

Blood clam shell powder was soaked using $3.5 \% \mathrm{NaOH}$ in a ratio of $1: 1 \mathrm{w} / \mathrm{v}$, heated in a saucepan at $100^{\circ} \mathrm{C}$ for 1 hour while stirring every 10 minutes. When finished, let it sit for a few hours until it cools and the shell powder settles, after that, the precipitate is filtered using a cloth while rinsing with sterile water/aquadest, then dried in an oven at $200^{\circ} \mathrm{C}$ for 20 minutes.

\subsection{Depigmentation}

Blood clam shell powder using $4 \% \mathrm{NaOCl}$ with a ratio of $2: 3 \mathrm{w} / \mathrm{v}$, heated in a saucepan at $100^{\circ} \mathrm{C}$ for 1 hour while stirring every 10 minutes. When finished, let it sit for a few hours to cool and the shell powder settles, after that, the precipitate is filtered using a cloth while rinsing with sterile water/aquadest, then dried in an oven at $200^{\circ} \mathrm{C}$ for 90 minutes.

\subsection{Deacetylation}

Blood clam shell powder was soaked using $50 \% \mathrm{NaOH}$ with a ratio of $1: 1 \mathrm{w} / \mathrm{v}$, then heated in a pan at $100^{\circ} \mathrm{C}$ for 2 hours while stirring every 10 minutes. When finished, let it sit for a few hours to cool, then filtered using a cloth while rinsing with sterile water/aquadest, then dried in an oven at $200^{\circ} \mathrm{C}$ for 90 minutes. After drying in the oven, the drying results are in the form of hard lumps which are ground to a fine powder.

\section{Results}

Clam shells have the potential to be used as chitosan because they contain chitin. Chitin content in blood clam shells is $14-35 \%$. The initial stage in the manufacture of chitosan is sample preparation which includes drying, refining and sifting as shown in Figure 1. The result of the extraction process of chitosan from blood clam shells (Anadara granosa) can be seen in Table1.

Table 1. The result of the extraction process of chitosan from blood clam shells (Anadara granosa)

\begin{tabular}{ccc}
\hline \multirow{2}{*}{ Stage } & \multicolumn{2}{c}{ Result } \\
\cline { 2 - 3 } & Color & Texture \\
\hline Demineralization & Grayish White & Heavy And Solid \\
Deproteination & Pure White & Easy Dry \\
Depigmentation & Pure White & Easy Dry \\
\hline
\end{tabular}

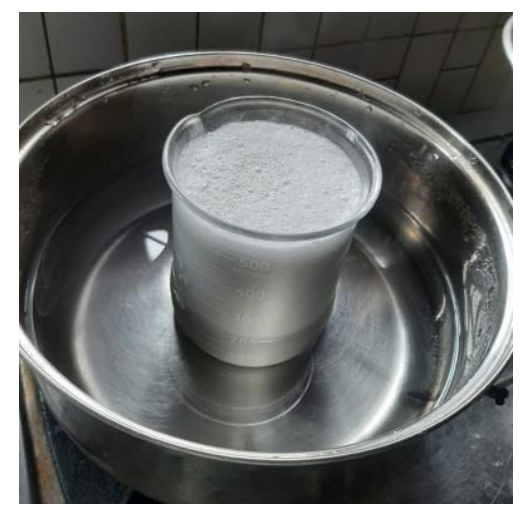

A

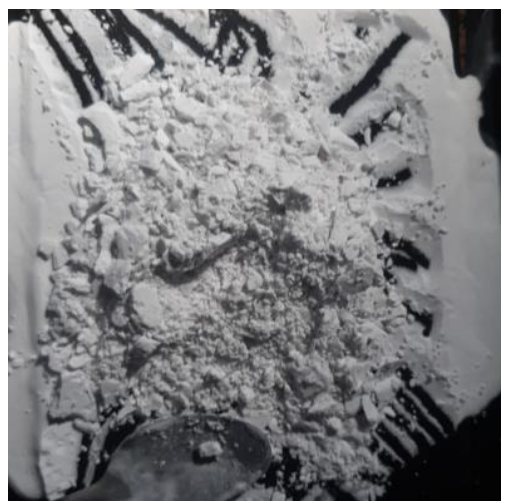

B

Figure 1. Chitosan manufacturing process : A. Demineralization, deproteination, depigmentation, deacetilation;

B. Chitosan powder after drying process. 


\subsection{Demineralization}

The extraction process of chitosan made from blood clam shells (Anadara granosa) goes through four stages, namely deproteination, demineralization, depigmentation, and deacetylation. The initial weight of the blood clam shell powder (A. granosa) obtained was 1500 grams. Blood clam shells contain organic and mineral salts, including $\mathrm{Ca} 3(\mathrm{PO} 4) 2(\mathrm{~s})$ and $\mathrm{CaCO} 3(\mathrm{~s})$, so it is necessary to carry out a demineralization process to remove mineral salts from the shells with the addition of hydrochloric acid $(\mathrm{HCl})$.

The initial step of this process is the addition of $1 \mathrm{~N} \mathrm{HCl}$ with a ratio of $1: 2 \mathrm{w} / \mathrm{v}$ into the shell powder. $\mathrm{HCl}$ was used to dissolve $\mathrm{Ca}$ ions. Mixing is done in a pan. The use of pans is done instead of beakers because all the manufacturing process is done at home (semi-manual). Then heated on the stove for 1 hour and stirred every 10 minutes. Heating in the demineralization process is carried out to accelerate the process of mineral destruction. In addition, stirring is required to avoid the overflow of $\mathrm{CO} 4(\mathrm{aq}) 2$ gas during the demineralization process. Washing is done in addition to neutralizing the residual $\mathrm{pH}$.

After drying, the result of the demineralization process is a grayish white powder with a dense and heavy texture. Demineralization process aims to remove mineral content $\left(\mathrm{CaCO}_{3}\right)$ or inorganic salts in the shell (Agarwal, and Aggarwal, 2015). The demineralization process is characterized by the presence of $\mathrm{CO}_{2}$ gas bubbles which are an indicator of the reaction between $\mathrm{HCl}$ and mineral salts in the shell.

\subsection{Deproteination}

Deproteination can be done with the addition of chemical reagents such as sodium hydroxide or enzymatically with the addition of protease enzymes. The deproteination stage was the blood clam shell powder added with $3.5 \% \mathrm{NaOH} 1$ $: 1 \mathrm{w} / \mathrm{v}$ then heated while stirring with a magnetic stirrer for 2 hours at a temperature of $65^{\circ} \mathrm{C}$. After cooling, filtered and neutralized with distilled water. The solid obtained was dried in an oven at $60^{\circ} \mathrm{C}$ to dry.

Deproteination process using 3.5\% $\mathrm{NaOH}$ aims to break the protein bonds, so that the protein contained in the shell will dissolve in hot $\mathrm{NaOH}$ and the protein will form Na-proteinate which will dissolve (De Queiroz Antonino et al., 2017). The result of this deproteination is chitin. Deproteination is a process to reduce protein content by an extraction process using a strong alkaline solution in concentrations from 3 to $6 \mathrm{~N}$ (Hanafi et al., 2000). Sometimes, the alkali used for this process is sodium hydroxide, sodium carbonate, potassium hydroxide or potassium carbonate. However, the use of sodium hydroxide is preferred because of its lower cost (Fernandez-Kim, 2004).

In general, the sequence of demineralization and deproteination processes can be carried out sequentially or not, namely the deproteination process is carried out first and then followed by the demineralization process using an acidic decalcification procedure, or a process with a sequence of demineralization processes followed by a deproteination process. Different sequences of this process can produce different chitosan (Hargono and Djaeni, 2003).

The results obtained from the deproteination process are the color of the powder becomes light white and the texture is easy to dry. Protein content after the reduction of the deproteination stage continued to decrease and was characterized by a color change (Abdou et al., 2008; Rhazi et al., 2000). The loss of protein content was indicated by a decrease in the intensity of the color of the solution becoming clearer (colorless) in the filtrate at the end of the treatment.

\subsection{Depigmentation}

Depigmentation is a process that aims to remove the color/pigment of chitin from blood clam shells. Depigmentation can be done using a bleaching agent in the form of $4 \% \mathrm{NaOCl}$ (Bahri et al., 2015). The depigmentation process was carried out by soaking the blood clam shell powder using $4 \% \mathrm{NaOCl}$ with a ratio of $2: 3$ $\mathrm{w} / \mathrm{v}$, then heated in a pan for 1 hour while stirring every 10 minutes. When finished, let it sit for a few hours to cool and the shell powder settles, after that, the precipitate is filtered using a cloth while rinsing with sterile water/aquadest, then dried in an oven at $200^{\circ} \mathrm{C}$ for 90 minutes.

Depigmentation process can be carried out using various chemicals, including acetone and $\mathrm{NaOCl}$. However, $\mathrm{NaOCl}$ is more often used because it produces a pure white color which indicates a complete depigmentation process. The use of acetone in the depigmentation process was not perfect if the color produced was yellowish white (Setha and Rumata, 2019). The most suitable concentration of $\mathrm{NaOCl}$ reduces pigment to a maximum of $4 \%$. This is because the higher the concentration of $\mathrm{NaOCl}$ at a certain limit, which is $4 \%$, causes higher chromophore damage so that the pigment content in the product is lower.

The result of the depigmentation process is blood clam shell powder with a clean white color and easy to dry. Depigmentation process resulted in the color of blood clam shells from gray to pure white (Windari et al., 2019). Indicators of the success of the depigmentation process can be seen directly without going through a certain test. The change in the color of the sample to pure white indicates a successful depigmentation process because it indicates that the pigment in the sample has been reduced. 


\subsection{Deacetylation}

Deacetylation is a process to convert chitin into chitosan using alkaline materials. Deacetylation process occurs due to the loss of the acetyl group $(\mathrm{CH} 3-\mathrm{CO})$ in chitin, which then produces a free amine group (-NH) so that chitin is reduced to chitosan (Rokhati, 2006). The deacetylation process on blood clam shells was carried out by soaking the blood clam shell powder using $50 \% \mathrm{NaOH}$ with a ratio of $1: 1 \mathrm{w} / \mathrm{v}$, then heated in a pan for 2 hours while stirring every 10 minutes. When finished, let it sit for a few hours to cool, then filtered using a cloth while rinsing with sterile water/aquadest, then dried in an oven at $200^{\circ} \mathrm{C}$ for 90 minutes. After drying using the oven, the drying results in the form of hard lumps are ground until smooth.

$\mathrm{NaOH}$ in the deacetylation process serves to reduce chitin to chitosan. $\mathrm{NaOH}$ has the highest alkaline strength among other alkaline materials so that it has a high ability to reduce chitin to chitosan and is suitable for use in the deacetylation process (Mursida et al., 2018). The concentration of $\mathrm{NaOH}$ used was $50 \%$ because the concentration produced chitosan with high enough purity. The highest degree of chitin deacetylation was produced by $50 \% \mathrm{NaOH}$. This shows that $50 \% \mathrm{NaOH}$ produces the purest chitosan because the higher the degree of deacetylation, the purer the chitosan produced (Bahri et al., 2015).

The reaction between $50 \% \mathrm{NaOH}$ solution and blood clam shell powder produces a mixture that is quite thick and pink in color. The reaction rate in the deacetylation process is largely determined by the type of heating used. Heating using a microwave causes chemical reactions to occur faster than using conventional heating such as heating in a pan. The results obtained from the deacetylation process are chitosan which is difficult to dry, has a dense and very hard texture, and the yield mass produced is less than the mass of the initial raw material. The mass yield of chitosan is influenced by several factors, including the concentration of $\mathrm{NaOH}$ used by temperature which can cause many acetyl groups to be released from the chitin polymer so as to produce chitosan with less yield but purer (Mursida et al., 2018).

\section{Conclusions}

Based on the research conducted, it can be concluded that the manufacture of chitosan from blood clam shell waste on a home scale can be done by pounding clam shells, isolating chitin through demineralization, deproteination, and depigmentation processes, and making chitosan from chitin through a deacetylation process using available tools at home as a substitute for laboratory equipment.

\section{Acknowledgements}

After this research, we would like to say thank to the organizers of the Student Creativity Program (PKM) 2021 who have provided financial support so that we can compile scientific articles properly.

\section{References}

Abdou, E. S., Nagy, K. S., \& Elsabee, M. Z. (2008). Extraction and characterization of chitin and chitosan from local sources. Bioresource technology, 99(5), 1359-1367.

Agarwal, S., \& Aggarwal, S. (2015). Mucoadhesive polymeric platform for drug delivery; a comprehensive review. Current drug delivery, 12(2), 139-156.

Al-Hetar, M. Y., Zainal Abidin, M. A., Sariah, M., \& Wong, M. Y. (2011). Antifungal activity of chitosan against Fusarium oxysporum f. sp. cubense. Journal of Applied Polymer Science, 120(4), 2434-2439.

Bahri, S., Rahim, E. A., \& Syarifuddin, S. (2015). Derajat deasetilasi kitosan dari cangkang kerang darah dengan penambahan naoh secara bertahap. KOVALEN: Jurnal Riset Kimia, 1(1), 36-42.

De Queiroz Antonino, R. S. C. M., Lia Fook, B. R. P., de Oliveira Lima, V. A., de Farias Rached, R. I., Lima, E. P. N., da Silva Lima, R. J., \& Lia Fook, M. V. (2017). Preparation and characterization of chitosan obtained from shells of shrimp (Litopenaeus vannamei Boone). Marine drugs, 15(5), 141-157.

Devi, A. R., Susilowati, A., \& Setyaningsih, R. (2019). Morphology, molecular identification, and pathogenicity of Vibrio spp. on blood clam (Anadara granosa) in Yogyakarta, Indonesia tourism beach areas. Biodiversitas Journal of Biological Diversity, 20(10), 1-12

Dewi, S. E., Eddiwan, E., \& Efawani, E. (2019). Morphometric and growth patterns of the blood clam (Anadara granosa) from the Bagan Siapi-Api coastal area Rokan Hilir. Berkala Perikanan Terubuk, 46(3), 37-45, 2890-2896. 
El Knidri, H., Belaabed, R., Addaou, A., Laajeb, A., \& Lahsini, A. (2018). Extraction, chemical modification and characterization of chitin and chitosan. International journal of biological macromolecules, 120, 1181-1189.

Fernandez-Kim, S. O. (2004). Physicochemical and functional properties of crawfish chitosan as affected by different processing protocols, Master of Thesis, Louisiana State University and Agricultural and Mechanical College

Hanafi, M., Amin, S., Efrina, D., \& Suwandi, B. (2000). The Use of Shrimp Shell for Chitosan and Glucosamine. Jurnal Kimia Terapan Indonesia, 10(2), 17-21.

Hargono, H., \& Djaeni, M. (2003). Utilization of chitosan prepared from shrimp shell as fat diluent. Journal of Coastal Development, 7(1), 31-37.

Hassan, O., \& Chang, T. (2017). Chitosan for eco-friendly control of plant disease. Asian J. Plant Pathol, 11, 53-70.

Kumirska, J., Czerwicka, M., Kaczyński, Z., Bychowska, A., Brzozowski, K., Thöming, J., \& Stepnowski, P. (2010). Application of spectroscopic methods for structural analysis of chitin and chitosan. Marine drugs, 8(5), 1567-1636.

Mursida, M., Tasir, T., \& Sahriawati, S. (2018). Efektifitas Larutan Alkali pada Proses Deasetilasi dari Berbagai Bahan Baku Kitosan. Jurnal Pengolahan Hasil Perikanan Indonesia, 21(2), 356-366.

Perikanan, K. K. (2011). Statistik Perikanan Tangkap Indonesia 2010. Jakarta: Direktorat Jenderal Perikanan Tangkap.

Rhazi, M., Desbrieres, J., Tolaimate, A., Alagui, A., \& Vottero, P. (2000). Investigation of different natural sources of chitin: influence of the source and deacetylation process on the physicochemical characteristics of chitosan. Polymer International, 49(4), 337-344.

Rokhati, N. (2006). Pengaruh derajat deasetilasi khitosan dari kulit udang terhadap aplikasinya sebagai pengawet makanan. Reaktor, 10(2), 54-58.

Setha, B., \& Rumata, F. (2019). Characteristics of Chitosan from White Leg Shrimp Shells Extracted Using Different Temperature and Time of the Deasetilation Process. Jurnal Pengolahan Hasil Perikanan Indonesia, 22(3), $498-507$.

Tolaimate, A., Desbrieres, J., Rhazi, M., \& Alagui, A. (2003). Contribution to the preparation of chitins and chitosans with controlled physico-chemical properties. Polymer, 44(26), 7939-7952.

Windari, N. N. R., Fauziah, S. I., Juniar, A. E., \& Purnomo, T. Biobakterisida Kitosan Cangkang Kerang Darah sebagai Anti Bakteri Ralstonia solanacearum. In Proceeding Biology Education Conference: Biology, Science, Enviromental, and Learning, 16(1), 280-284.

Yurimoto, T. (2013). Development of blood cockle aquaculture management techniques in Malaysia. JIRCAS Newsletter, 69(6), $1-12$. 